\title{
A Study on Development of Agraria Research and Innovation System in Bulgaria
}

Hrabrin Bachev: Institute of Agricultural Economics, Sofia, Bulgaria.

\begin{abstract}
Despite the great theoretical and practical significance, in Bulgaria there are no comprehensive analysis of the state and evolution of agrarian research and development (ARD) activities in public and private sectors. The goal of this paper is to analyze the state and evolution of ARD in Bulgaria during the period after country's EU accession in 2007, identify major trends in that area, make a comparison with other EU states, specify main problems, and suggest conclusions for improvement of policies during next programing period. The analysis has found out that in years of EU membership the expenditures for ARD significantly decreased absolutely and relatively as a share in the total expenditures for $R \& D$, which indicates diminishing importance, and deteriorating financial, personnel and material potential of agrarian knowledge and innovation sector. The most important sector for ARD in the country is the government in which more than $80 \%$ of overall expenditures for ARD are invested, as distribution of expenditures and organization of $R \& D$ in major sectors differ considerably from other EU member states. ARD in the country mainly are funded by the state budget, and the importance of budget financing relatedly increases during the period, unlike trends in other EU countries.
\end{abstract}

Key words: Research and development, Agriculture, Sectors, Funding, AKIS, Bulgaria

\section{Introduction}

Rapid development and modernization of research and innovation sphere in general, and in agriculture in particular, has been an important priority of the EU policies in the last decades. „Stimulation and sharing of knowledge, innovation and digitalization- have been defined as one of the strategic (a „horizontal-) objectives of the European Union (EU) Common Agricultural Policy (CAP) during the next 2021-2027 programing period as well (European Commission, 2018). Agrarian research and development activity is an important part of the knowledge sharing and innovation system ${ }^{1}$ in that important sector of European economy contributing to achievement of all strategic goals of EU CAP.

In other EU and non-EU countries there have been carried profound analyses of the state and evolution of agrarian research and development systems (Anandajayasekeram \& Gebremedhin, 2009; Antle, Jones, \& Rosenzweig, 2017; Chartier, Doghmi, Fourcin, Broek, \& Midmore, 2015; FAO, 2019; Mykhailova, Stoyanets, Mykhailov, Kharchenko, \& Bachev, 2018; Ozçatalbaş, 2017; Touzard, Temple, \& Triomphe, 2015; USDA, 2019; Virmani, 2013; Weißhuhn, Helming, \& Ferretti, 2018; World Bank, 2006). However, in Bulgaria with very few exceptions (Bachev \& Labonne, 2000; Bachev \& Mihailova, 2019; Eurostat, 2019) there are no comprehensive studies on the state and evolution of agrarian research and development activity before and since the accession of the country to EU in 2007. The latter is a consequence both of the lack of sufficient official statistical, report etc. data as well as public interest in development of that important system.

This paper tries to analyze the state and evolution of agrarian research and development activity in Bulgaria during the EU membership years. The goal is to specify major trends, make a comparison with other

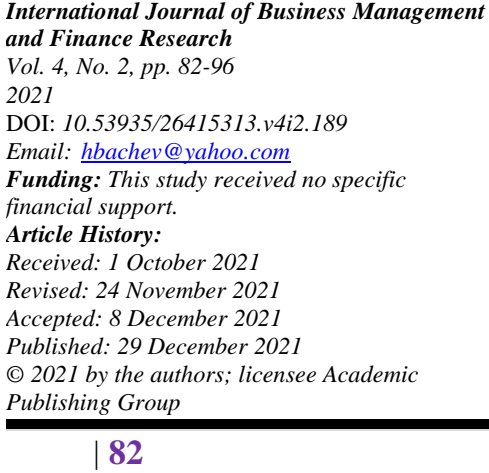


EU states, identify main challenges, and assist policies during the next programing period (Ivanov et al., 2020).

\section{Personnel and Expenditures for Agrarian Research and Development}

Agrarian Research and Development (ARD) includes „every creative work, undertaken systematically, and aiming at increasing the body of knowledge, including knowledge about human, culture and society, as well as utilization of that body of knowledge in new applications- (NSI). It encompasses fundamental and applied research and experimental works.

ARD in Bulgaria is mostly carried out by public organizations - research institutes and experimental stations of Agricultural Academy, some institutes of Bulgarian Academy of Sciences (Institute of Plant Physiology and Genetics, Institute of Economic Studies, etc.), some of public and private universities (Agrarian University, Trasia University, Russe University, Forestry University, University of National and World Economy, High School for Agribusiness and Regional Development, etc.), and to a smaller extent by private firms and organizations, non- governmental organizations, etc.

ARD in the country if funded by the state budget (e.g. National Science Fund, National Innovation Fund, state subsidies for Bulgarian Academy of Sciences and Agricultural Academy, etc.), business organizations (own and landed investments for internal R\&D, purchase of intellectual property, commissioning research, sponsorship, etc.), non-governmental organizations, foreign states, international organizations (e.g. EU HORIZON 2020 Program, FAO projects, etc.), private individuals, etc.

„Expenditures for research and development activityll include the current costs and the costs for acquiring long- term material assets, for research and development (R\&D) within a statistical unit, independent from the source of funding (NSI). Level of dynamics of that indicator gives insight for the state, financial and material conditions and armament as well as for the evolution of the system for generation, sharing and dissemination of knowledge and innovation in agrarian sphere.

In the past years the expenditures for R\&D activity in „Agricultural Sciences- have diminished considerably both absolutely as well as a relative share in the total expenditures for R\&D activity in the country (Figure 1). While the overall amount of the expenditures for R\&D activity has increased almost three times after 2007, the expenditures for R\&D activity in „Agricultural Sciences- have diminished with $45 \%$ until 2014, and demonstrate a growth afterwards reaching a three-quarters of the initial level in 2017.

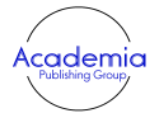

International Journal of Business Management and Finance Research Vol. 4, No. 2, pp. 82-96

2021

DOI: $10.53935 / 26415313 . v 4 i 2.189$

Email: hbachev@yahoo.com

Funding: This study received no specific

financial support.

Received: 1 October 2021

Revised: 24 November 2021

Accepted: 8 December 2021

Published: 29 December 2021

(๑) 2021 by the authors; licensee Academic Publishing Group

83

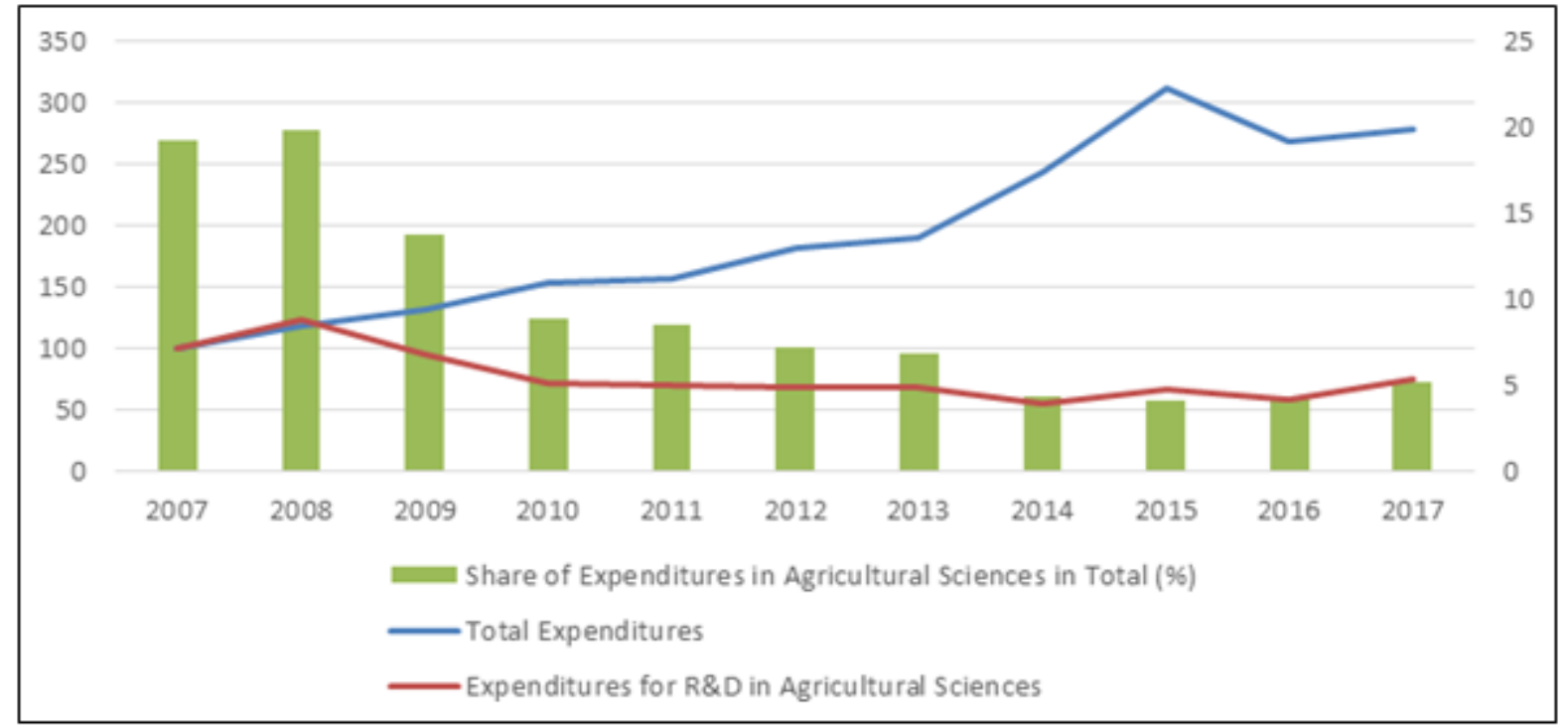

Figure-1. Evolution of Expenditures for R\&D Activity Total for Bulgaria and for Agricultural Sciences (2007=100) Source: NSI National Statistical Institute (2019)

Simultaneously, the share of the expenditures for R\&D activity in „Agricultural Sciences- have experienced a significant drop in the total expenditures for R\&D activity of the country - from around a fifth in 2008 г., to a little more than 4\% during 2005-2016, and just above 5\% in the end of the period. These data 
indicate a diminishing importance of the agrarian knowledge and innovation sector in the overall system of knowledge and innovation of the country.

The indicator „Personnel employed in R\&D activity\| measures the human resources directly involved in R\&D activity, who are responsible for generation, application and dissemination of the new knowledge (NSI). It comprises persons, directly carrying $R \& D$ activity and persons, directly supporting $R \& D$ activity (managers, administrators, bureaucracy, etc.). The level and dynamics of that indicator shows the staff endowment of the system of R\&D activity in the sector.

Since 2007 personnel employed in R\&D activity in the area of „Agricultural Sciences- initially augment (up to $12 \%$ in 2010), and gradually decreases afterwards to $78 \%$ of the initial level in 2017 (Figure 2). That indicates deteriorating of the staff component of $\mathrm{R} \& \mathrm{D}$ activity in agrarian sphere in recent years.

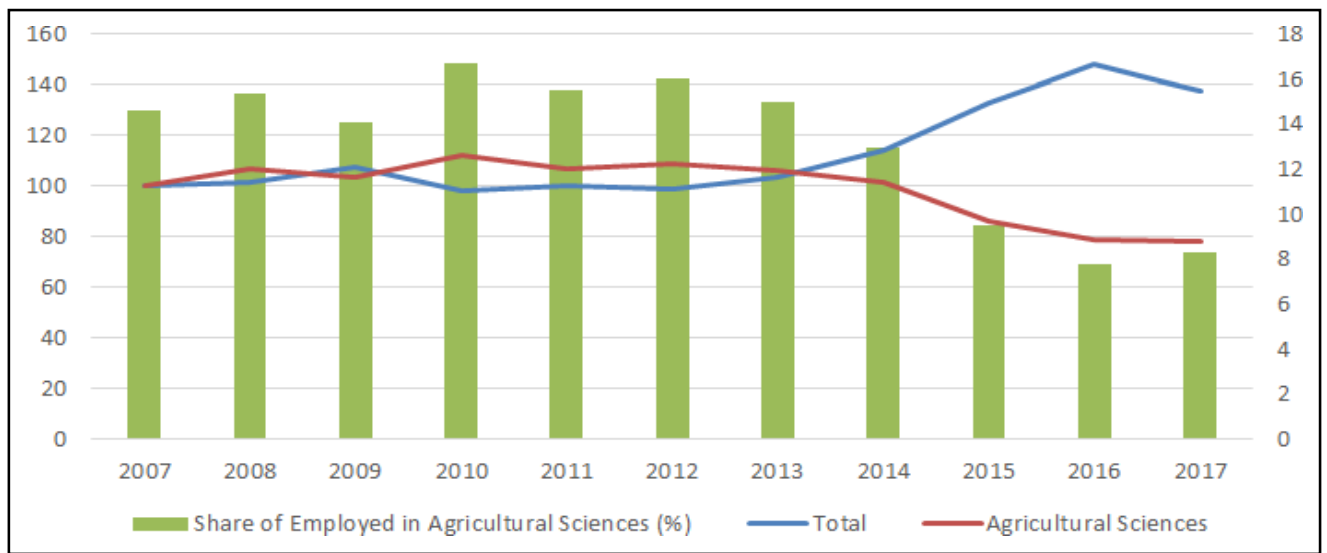

Figure-2. Evolution of Employed in R and D activity Total for Bulgaria and in Agricultural Sciences, in Full-time Equivalent $(2007=100)$.

Source: NSI National Statistical Institute (2019).

Simultaneously, there has been a change in the share of the involved with agricultural sciences in the total number of employed in R\&D activity. Until 2012 their portion augments from 14,6\% to 16\%, and after that decline twice in the last two years.

Along with the worsening of the personnel armament of R\&D activity in agricultural sciences, there is also a decline in the material and financial endowment of the employed in R\&D activity in agricultural sciences. After accession of the country to EU the expenditures for R\&D activity per one employed in agricultural sciences fall with more than $45 \%$ by 2014 (Figure 3). Since then their amount gradually augments reaching $96 \%$ of the level at the beginning of the period.

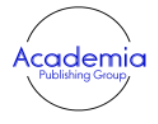

International Journal of Business Management and Finance Research

Vol. 4, No. 2, pp. 82-96

2021

DOI: $10.53935 / 26415313 . v 4 i 2.189$

Email: hbachev@yahoo.com

Funding: This study received no specific

financial support.

Received: 1 October 2021

Revised: 24 November 2021

Accepted: 8 December 2021

Published: 29 December 2021

() 2021 by the authors; licensee Academic Publishing Group

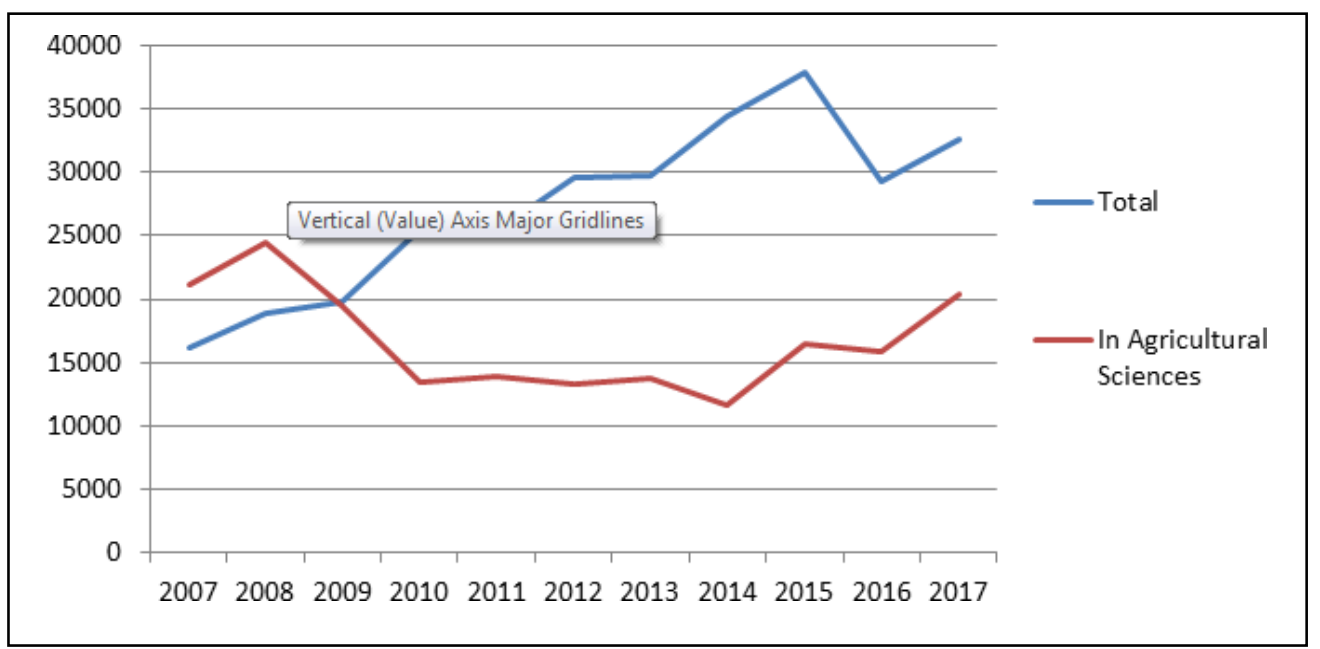

Figure-3. Amount of Expenditures per One Employed in R and D Activity Average for Bulgaria and in Agricultural Sciences (BGL)

Source: NSI National Statistical Institute (2019). 
During the same period there is a positive tendency for a rise of the average expenditures for $R \& D$ activity per one employed in R\&D activity in the country. What is more, while in first two years of the analyzed period the expenditures for $R \& D$ activity per one employed in Agricultural $R \& D$ activity considerably overpass the average in the country (with around 30\%), in 2017 г. they account for merely $63,3 \%$ of the average level.

These trends in the evolution of agrarian R\&D activity in Bulgaria are similar to other EU member states like Spain, Croatia, Slovakia and Lithuania, where it has been registered diminution of expenditures for R\&D activity in agriculture in the last years (Figure 4). At the same time in certain EU member states like Estonia, Hungary, Slovenia etc. there has been a significant growth in the overall expenditures for R\&D activity in the sector.

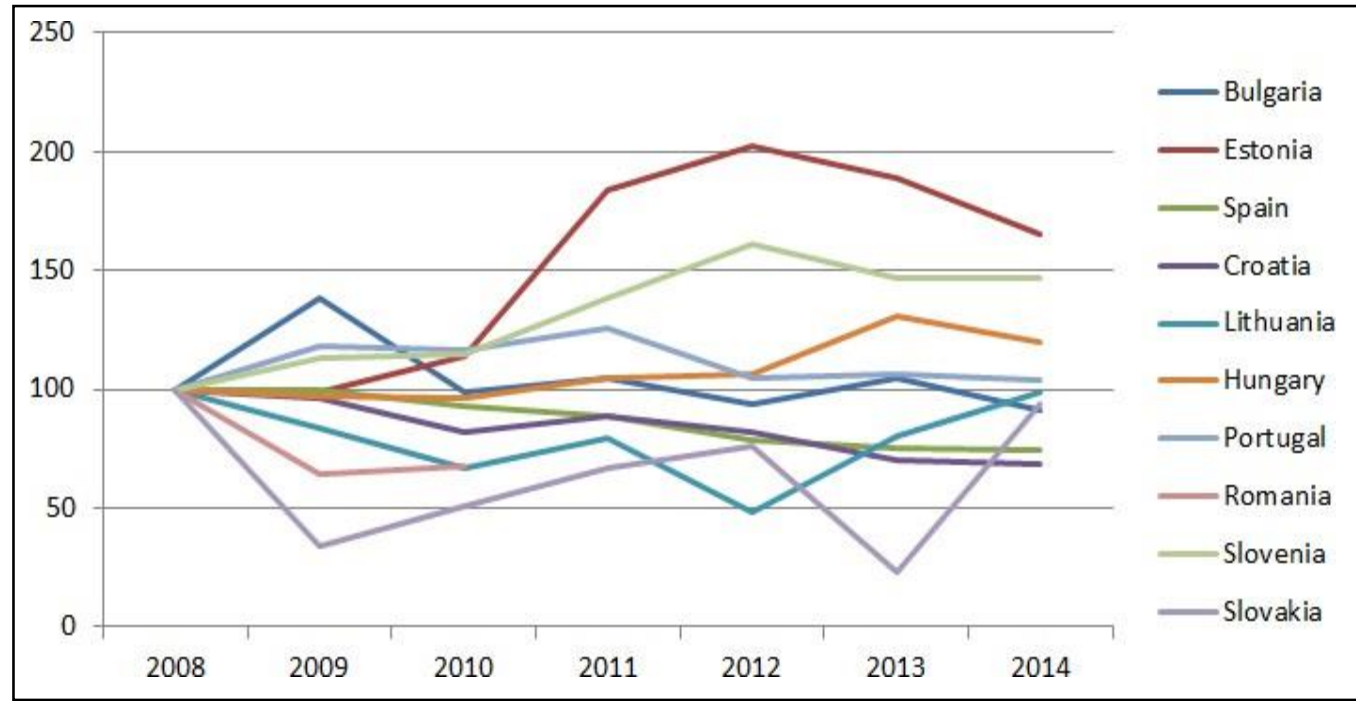

Figure-4. Evolution of Intramural R and D Expenditures in Sector - Agriculturell in EU Member States $(2008=100)$.

Source: Eurostat (2019).

In many EU countries there is a tendency for reduction of the relative share of expenditures for agrarian R\&D activity in the total for the country. Nevertheless, Bulgaria is among EU countries (along with Croatia, Romania, Hungary, etc.), in which the portion of expenditures for agricultural R\&D activity in the overall of the country continues to be the highest (Figure 5). On the other hand, in Slovenia the share of that type of expenditures for R\&D activity is insignificant.

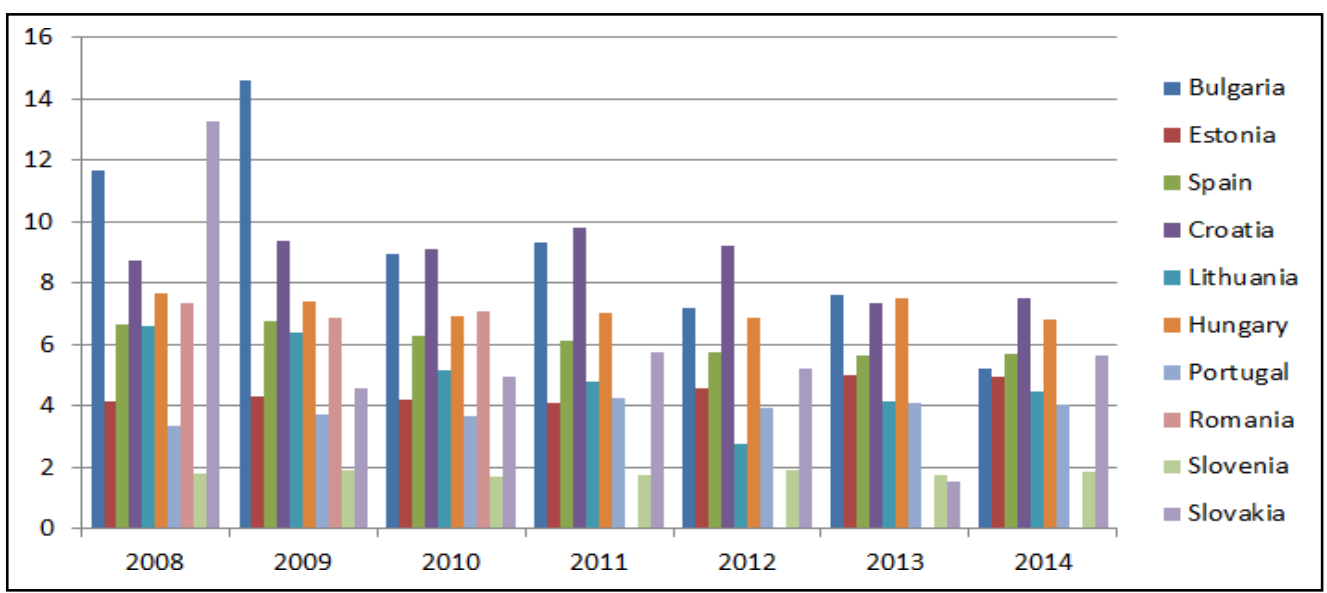

Figure-5. Share of Intramural R\&D Expenditures in Sector - Agriculturell in Total in EU Member States $(\%)$.

Source: Eurostat (2019)

Email: hbachev@yahoo.com

Funding: This study received no specific

Article History:

Received: 1 October 2021

Revised: 24 November 2021

Accepted: 8 December 2021

() 2021 by the authors; licensee Academic Publishing Group 
A common tendency in many EU countries is a diminution of the personnel and researchers in agrarian R\&D activity (Figure 6). The exception are Netherlands, Portugal and Slovakia, where there is a considerable augmentation of cadre endowment of agricultural R\&D activity.

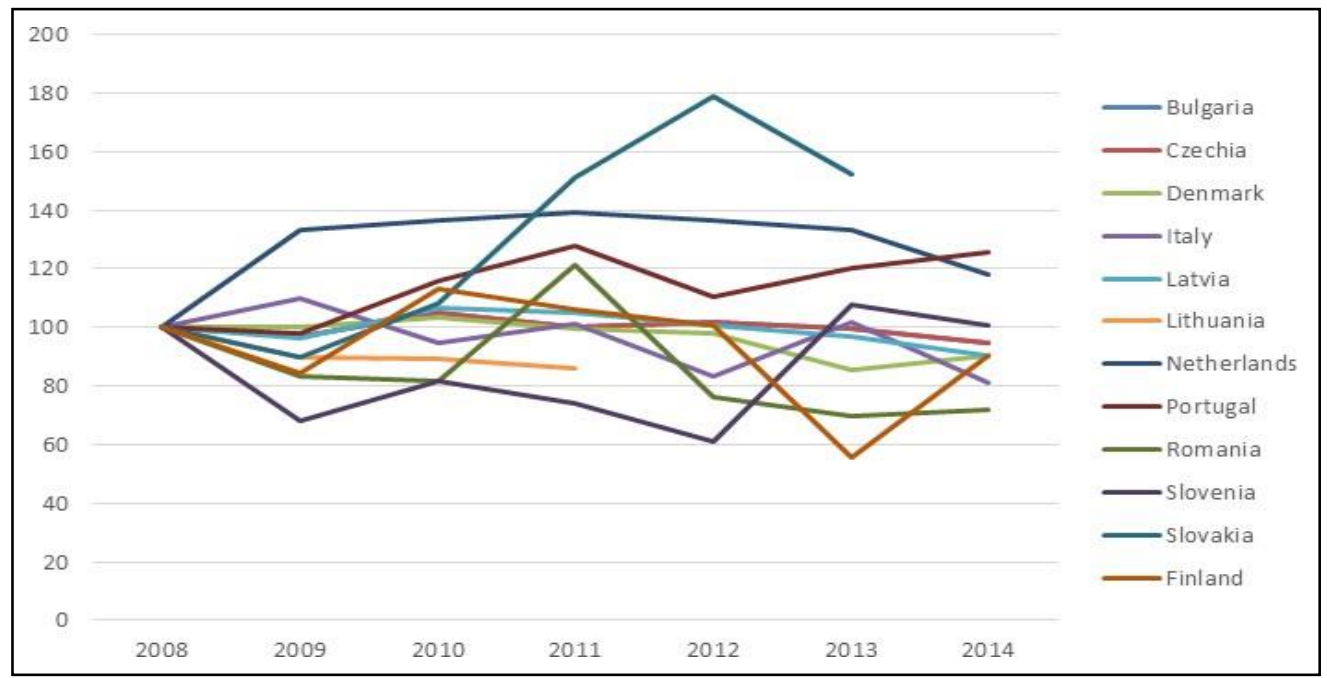

Figure-6. Evolution of R\&D Personnel and Researchers (Full-time Equivalent) in -Agricultural Sciences\| in EU Member States $(2008=100)$ Source: Eurostat (2019).

In many EU countries there is also a reduction, to a greater or lesser extent, of the share of personnel and researchers in agricultural R\&D activity in the total of the country (Figure 7).

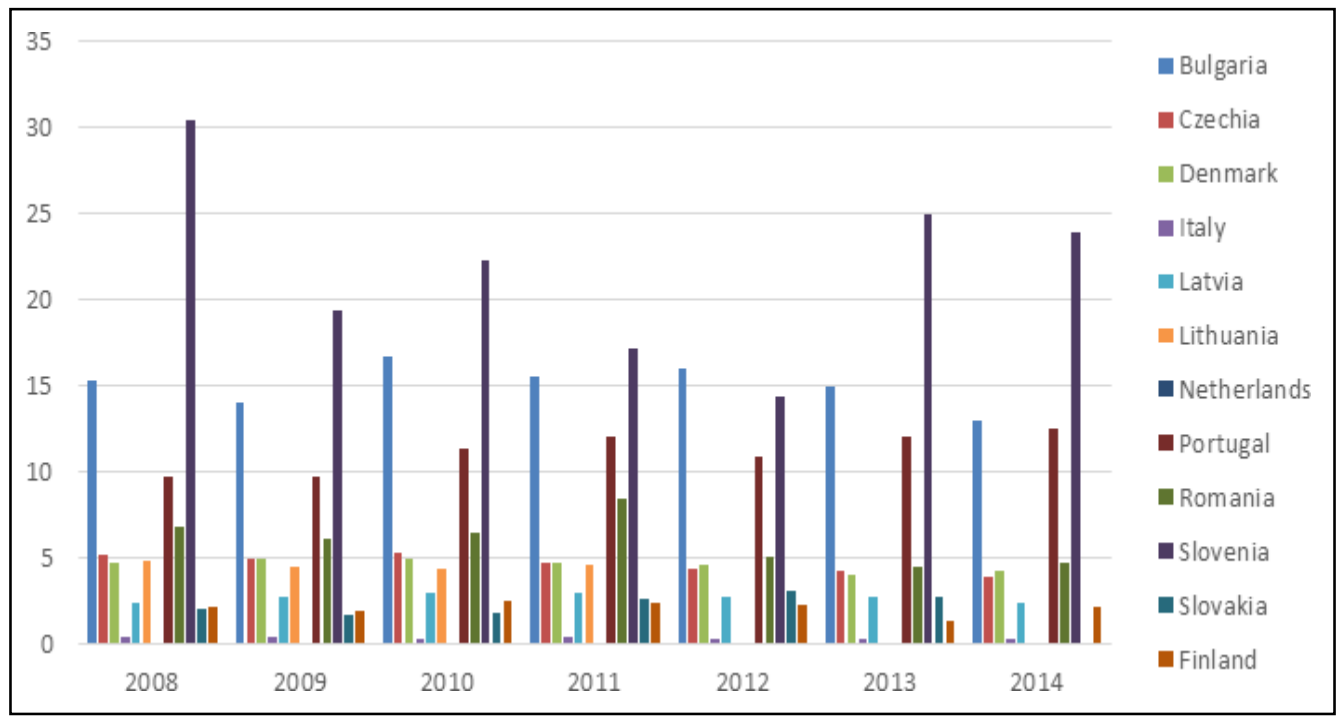

Figure-7. Share of R\&D Personnel and Researchers in -Agricultural Sciences\| in Total for the Country in EU Member States (\%).

Source: Eurostat (2019).

International Journal of Business Management and Finance Research

Vol. 4, No. 2, pp. 82-96

2021

DOI: 10.53935/26415313.v4i2.189

Email: hbachev@yahoo.com

Funding: This study received no specific

financial support.

Received: 1 October 2021

Revised: 24 November 2021

Accepted: 8 December 2021

Published: 29 December 2021

() 2021 by the authors; licensee Academic Publishing Group

However, in Latvia, Portugal and Slovakia there is a reverse trend of enlargement of the later proportion. Slovenia, Bulgaria and Portugal are countries with the greatest relative share of employed in agricultural sciences in the overall employed in R\&D activity.

In most of EU member states there is a similar trend like in Bulgaria for a greater or less significant reduction of financial endowment of employed in agrarian R\&D activity (Figure 8). Despite that however, the expenditures for R\&D activity for one employed in R\&D activity in sector Agricultural Sciences in Bulgaria are among the lowest in EU, similar to Slovenia. Regardless of the sensitive decline in the expenditures for 
one employed in agrarian R\&D activity in Slovakia during the period, their amount is 2,7 folds higher than the figure in Bulgaria (2013).

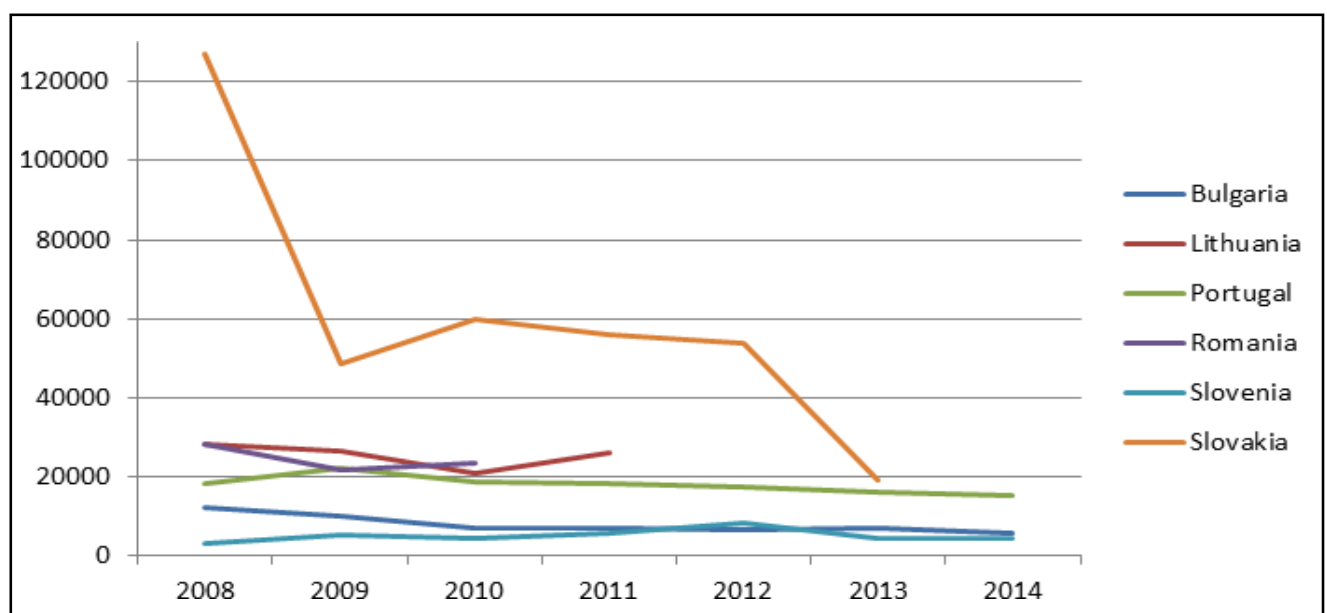

Figure-8. Intramural R\&D Expenditures in Sector -Agriculturel per Full-time Equivalent in Agricultural sciences in EU Member States (Euro).

Source: Eurostat (2019).

\section{Science Endowment of Agriculture}

An important indicator for science armament of agricultural production is the share of expenditures for agrarian R\&D activity in the Gross Value Added of the sector. Since the accession of the country to EU there is a considerable diminution of the expenditures in R\&D activity in sector Agricultural Sciences in the Gross Value Added of the sector „Agriculture, Forestry and Fishery- (Figure 9). In 2014 that indicator is 2,3 folds smaller than the 2007 level. In the last three years there is improvement in the level of ,science armament of the sector, but levels are far below the levels for the period before 2012.The opposite is the tendency in dynamics of the indicator share of total expenditures for R\&D activity in the Gross Value Added of the country. There is a positive increase of the scientific endowment as in 2015 this share doubled in comparison with the 2007 level. While in the beginning of the period the scientific endowment of the entire economy was 3,5 times lower that in the agrarian sector, it already overpasses the later during 2014-2016. As a result of the evolution of the expenditures for R\&D activity and the Gross Value Added in 2017 agriculture demonstrates again a little higher level for this indicators - $0,96 \%$ (against $0,87 \%$ before).

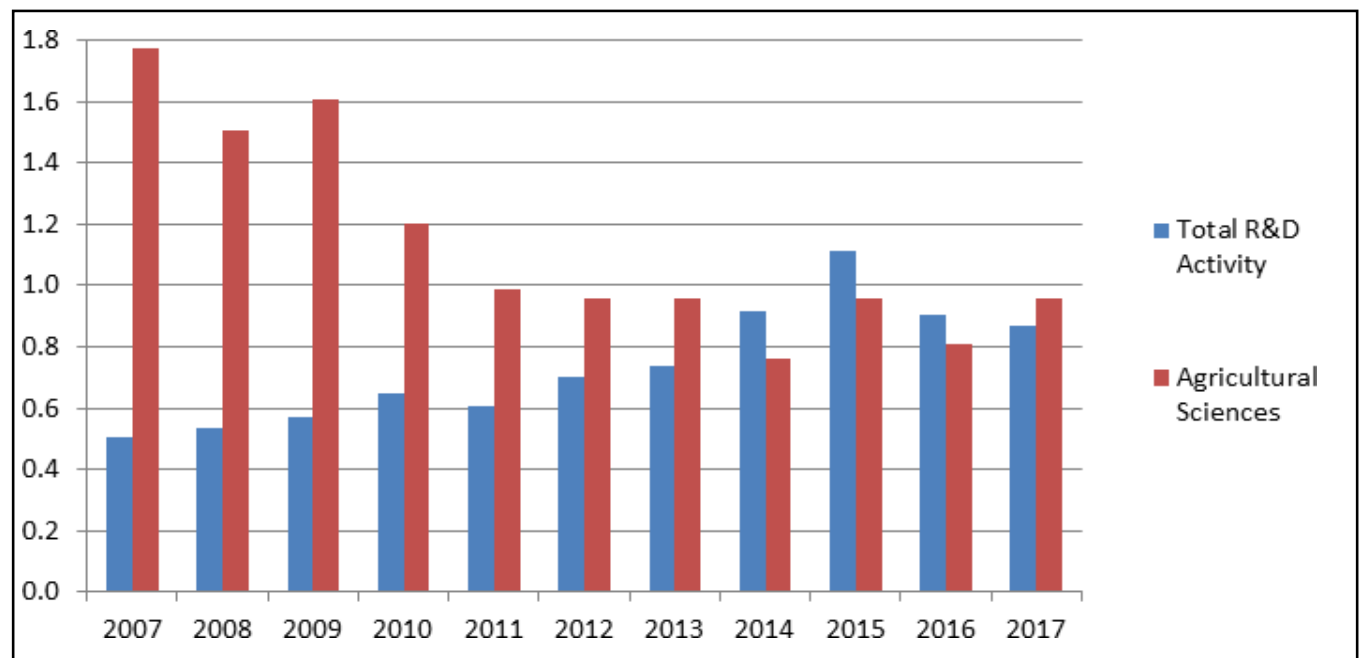

Figure-9. Share of Total and Agricultural Sciences Expenditures for R\&D Activity in the Gross Value Added of Bulgaria and „Agriculture, Forestry and Fishery- Sector (\%)

Source: NSI National Statistical Institute (2019) 
It is obvious, that with such pace of progression of investments in $R \& D$ activity hardly can be achieved both the EU goals for the amount of investments in R\&D activity at 3\% of the Gross Value Added in 2020 as well as the national objective of 1,5\%. Science endowment of the Bulgarian agriculture, measured through expenditures for R\&D activity in Gross Value Added, is among the lowest in EU along with Romania (Figure 10). In many member states (Estonia, Spain, Lithuania, Hungary, Portugal) the share of expenditures for agricultural R\&D activity in the Gross Value Added of the sector falls during the period 2009-2014 (for which there are comparative data), but exceeds considerably that of Bulgaria during entire period. In another group of countries like Croatia and Slovenia the level of this indicators are stable and higher than in Bulgaria throughout the period. On the other hand, there is a significant growth of the initial level up to amounts exceeding that of Bulgaria, but inferior in comparison to other member states.

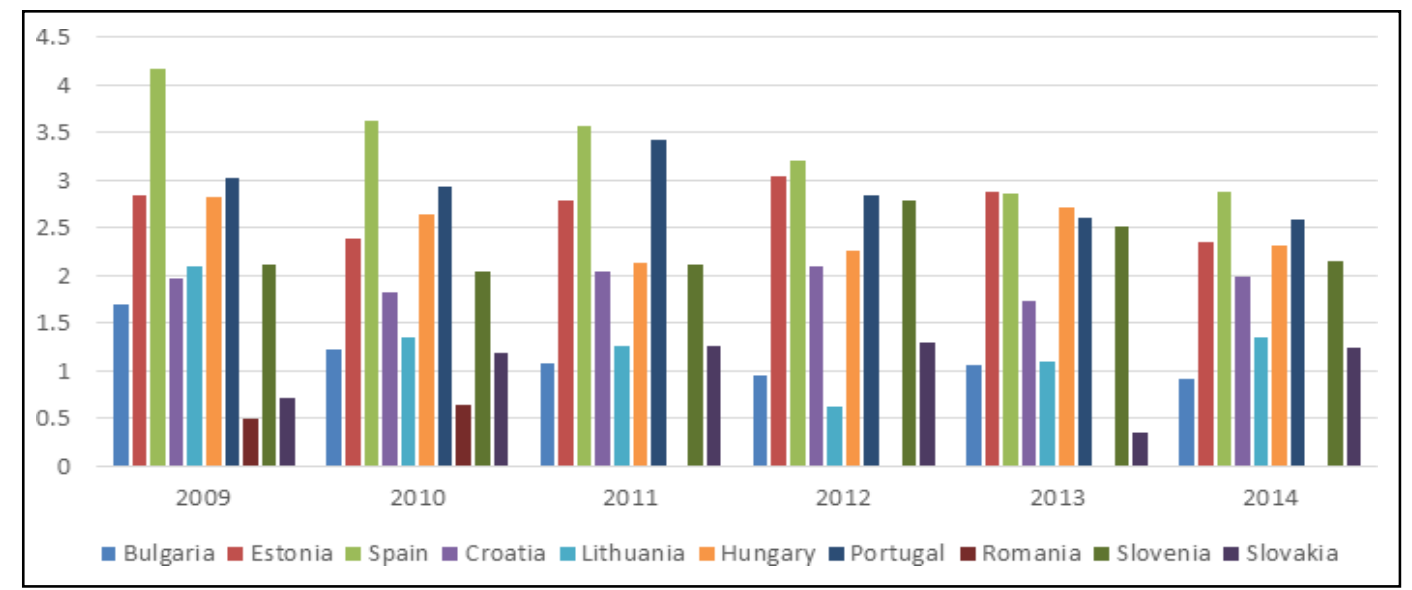

Figure-10. Share of Intramural R\&D Expenditures in Sector -Agriculturell in the Gross Value Added and Income in the ,Agriculture, forestr y and fishing- Sector in EU Member States (\%)

Sector: Eurostat (2019)

Another important indicator for science endowment of agriculture is the share of employed in agrarian $R \& D$ activity in the totally engaged in agricultural activity. In Bulgaria the share of employed in R\&D activity in the Collective workforce- of the sector progressively grows during the period 20092015 г. and fluctuates insignificantly afterwards. The endowment of the sector with workers in R\&D activity grows due to the greater reduction of number of employed in agriculture and working time in comparison to diminution of the personnel and researchers in agrarian R\&D activity (Figure 11).

International Journal of Business Management and Finance Research Vol. 4, No. 2, pp. 82-96

2021

DOI: $10.53935 / 26415313 . v 4 i 2.189$

Email: hbachev@yahoo.com

Funding: This study received no specific

financial support.

Received: 1 October 2021

Revised: 24 November 2021

Accepted: 8 December 202

Published: 29 December 2021

() 2021 by the authors; licensee Academic Publishing Group

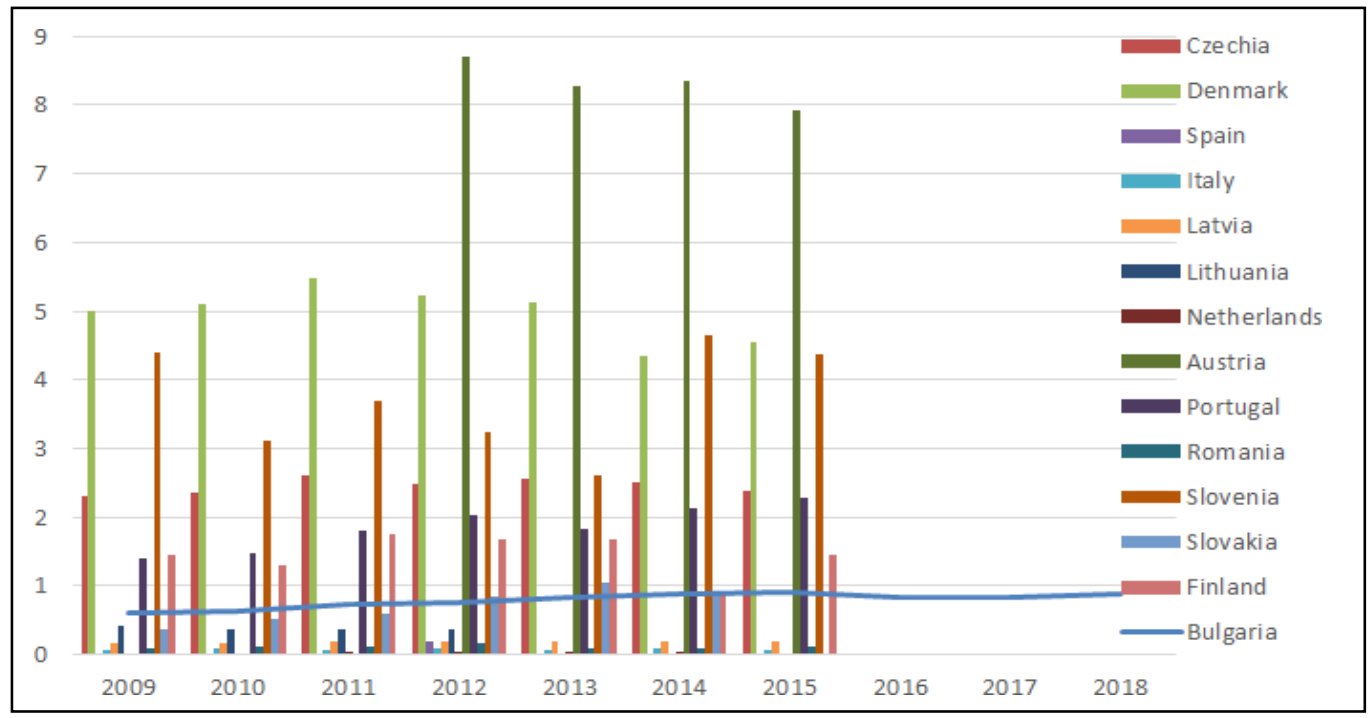

Figure-11. Share of Employed in R\&D Activity in Sector Agricultural Sciences (Full-time Equalent) in Total Workforce of Agriculture (Annual Work Units) in EU Member States (\%)

Source: NSI National Statistical Institute (2019) 
In most EU member states during the period 2009-2016 a stable level of science endowment is observed measured by that indicator. In some countries, like Italy, Spain, Latvia, Netherlands and Romania, the proportion of employed in agrarian R\&D activity in relations to the overall involved in the sector, is much lower than in Bulgaria. In Slovakia, the level of this indicator is similar to Bulgaria during the good part of the analyzed period.

However, most EU member states significantly surpass Bulgaria in relation to the number of employed in agrarian R\&D activity ,serving - the employed in agriculture. With the highest endowment of workers in agrarian R\&D activity is Austrian agriculture, which is 8,7 folds higher than in Bulgarian in 2016. During the analyzed period in Austria for every 100 employed in farming there are around 8 researchers and persons in R\&D activity in Agricultural Sciences, which also explains the big achievements of that country in generation, sharing and dissemination of knowledge and innovations.

\section{Evolution of Major Sectors of Agricultural R and D Activity}

Expenditures and personnel potential (capability) of R\&D activity are divided in four institutional sectors:

- Business Enterprise Sector, including all firms, organizations and institutions, having a main activity of production of market goods and services (without including those, which are included in sector „Higher Education -);

- Governmental Sector, including state organizations and institutions, which do not sell but provide services for satisfying individual and collective needs of society and funded mainly by the budget (without including those, which are included in sector „Higher Education -);

- Sector Higher Education, including universities, colleagues, high schools, research sectors belonging to high schools and university hospitals;

- Sector of Private Non-for-profit Organizations, including foundations, associations, partnerships etc. providing non-market services.

The level, relative share and dynamics of relevant indicators for these sectors of R\&D give insight on the state, development and importance of major sectors for carrying out agrarian R\&D activity in the country.

The most important sector of agricultural R\&D activity in Bulgaria is the Governmental sector, in which the greatest part of the total expenditures of R\&D activity in the sector are invested (Figure 12). With an exception of 2008 during entire period after EU accession of the country, in the later sector are allocated more than $80 \%$ of overall expenditures for agrarian R\&D activity. That sector comprises mostly research and development organizations, funding their activities from the state budget by priorities determined by the state.

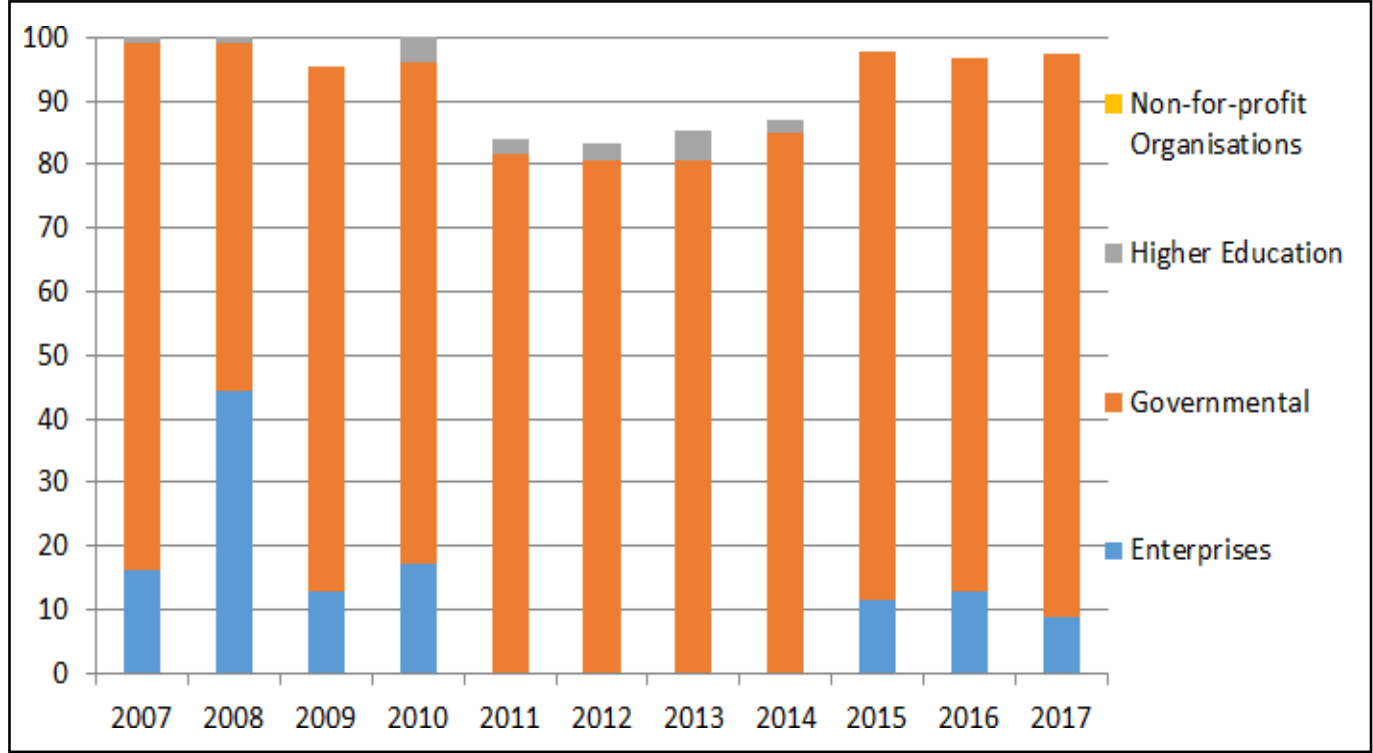

Figure-12. Share of Expenditures for Agricultural R\&D Activity in Major Sectors of R\&D Activity in Bulgaria (\%).

Source: NSI National Statistical Institute (2019) 
The second most important sector is that of Private Enterprises, which comprises mainly private firms and organizations managing their investments and activity for benefit of owners and according to the rules of market competition. The share of this sector in the total expenditures for agrarian R\&D activity considerably varies during the period, being higher during first four years (13-44\%), after that there are no data, and in the last three years lower $(9-13 \%)$.

The third by volume of expenditures for agricultural R\&D activity is the sector Higher Education, in which are allocated quite a different portion of the overall expenditures, varying from $0,8 \%$ up to approximately $5 \%$ in individual years, for which data are available.

In the sector of Non-for-profit Organizations are reported expenditures for agricultural R\&D activity only for $2008 \Gamma$. and they account for a tiny portion $(0,01 \%)$ of the total expenditures in the country.

Distribution of costs and organization of $R \& D$ activity in the major sectors of agrarian $R \& D$ in Bulgaria differ substantially from other EU member states (Figure 13). In most countries the governmental sector for agrarian R\&D activity dominates, but in Bulgaria its share surpasses two and more folds the portion in other member states, for which data are available. In Slovenia expenditures for agrarian R\&D activity in the sector Higher Education are the greatest (43\% during the period 2008-2012), while in the rest of the countries considerable (a third in Romania, 28\% in Spain, and 27\% in Hungary).

Unlike Bulgaria in other member states a strong private (business) sector of agrarian R\&D activity is also developing, in which are invested a significant part of the total expenditures - a little more than one third in Hungary, almost 29\% in Romania, approximately $27 \%$ in Spain, and $24 \%$ in Slovenia. All these indicates unbalanced development of main sector of agrarian R\&D activity in Bulgaria in a direction different from the common trends in EU and other developed countries.

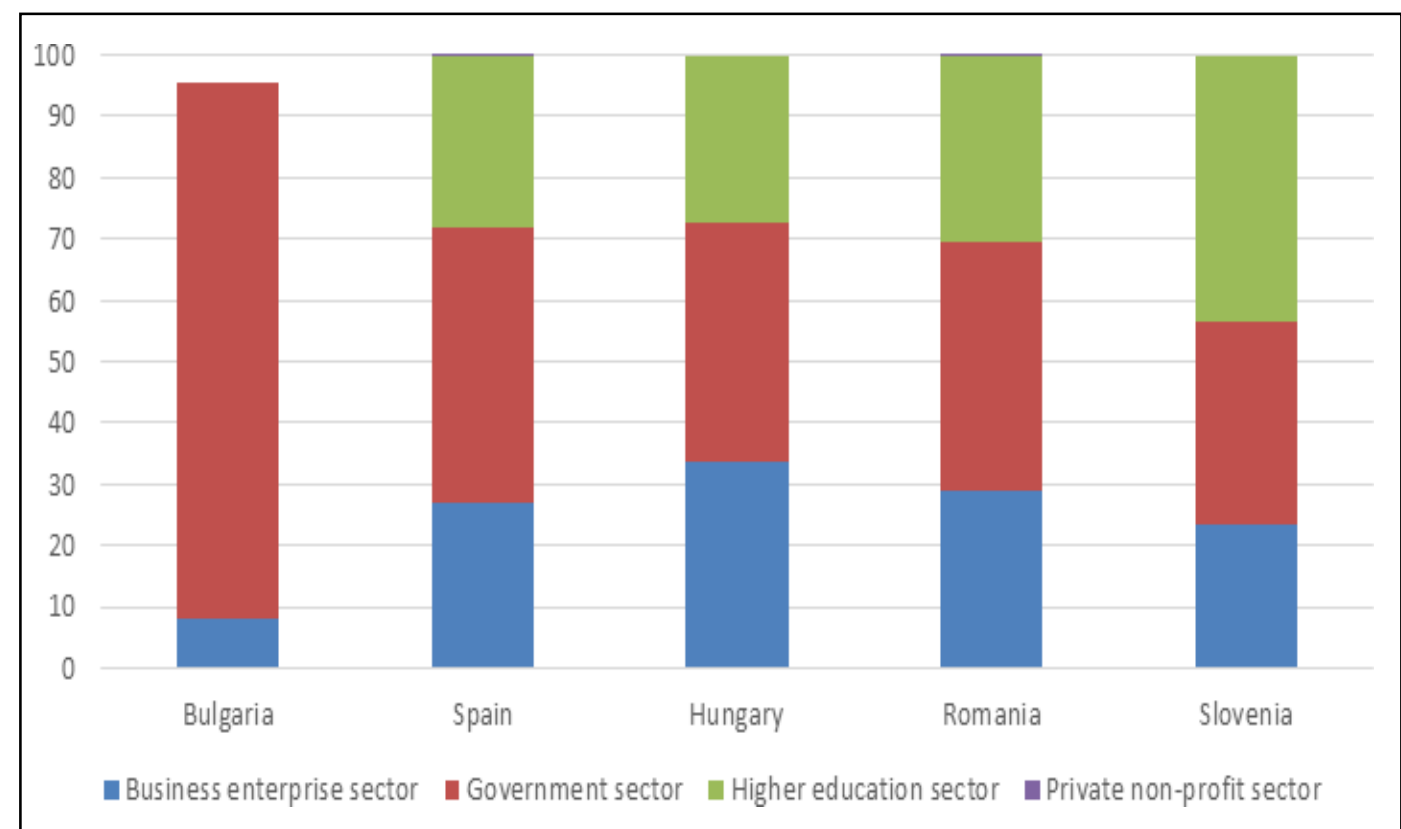

Figure-13. Share of Agricultural R and D Expenditures in Major Sectors of EU Member States for 2008-2012.

Source: Chartier et al. (2015).

International Journal of Business Management and Finance Research

Vol. 4, No. 2, pp. 82-96

2021

DOI: $10.53935 / 26415313 . v 4 i 2.189$

Email: hbachev@yahoo.com

Funding: This study received no specific

financial support.

Article History:

Received: 1 October 2021

Revised: 24 November 2021

Accepted: 8 December 2021

Published: 29 December 2021

(1) 2021 by the authors; licensee Academic Publishing Group

\section{0}

Similar to Bulgaria in the rest of analyzed countries the share of the Private Non-profit sector in the overall amount of agrarian R\&D activity is negligible.

The level of expenditures in major sectors of agrarian R\&D activity in Bulgaria is with different dynamics since 2007 (Figure 14). While in the sector Higher Education there is a growth of expenditures for agrarian R\&D activity, the Government and the Private sectors experience decline. Moreover, the diminution of the expenditures in the Private sector is much bigger than in the Government sector. Furthermore, since 2010 now dynamics of the expenditures for governmental $R \& D$ activity coincides with the dynamics of the total expenditures for agrarian $R \& D$ activity in the country, which confirms the leading role of that sector for $R \& D$ in agriculture. 


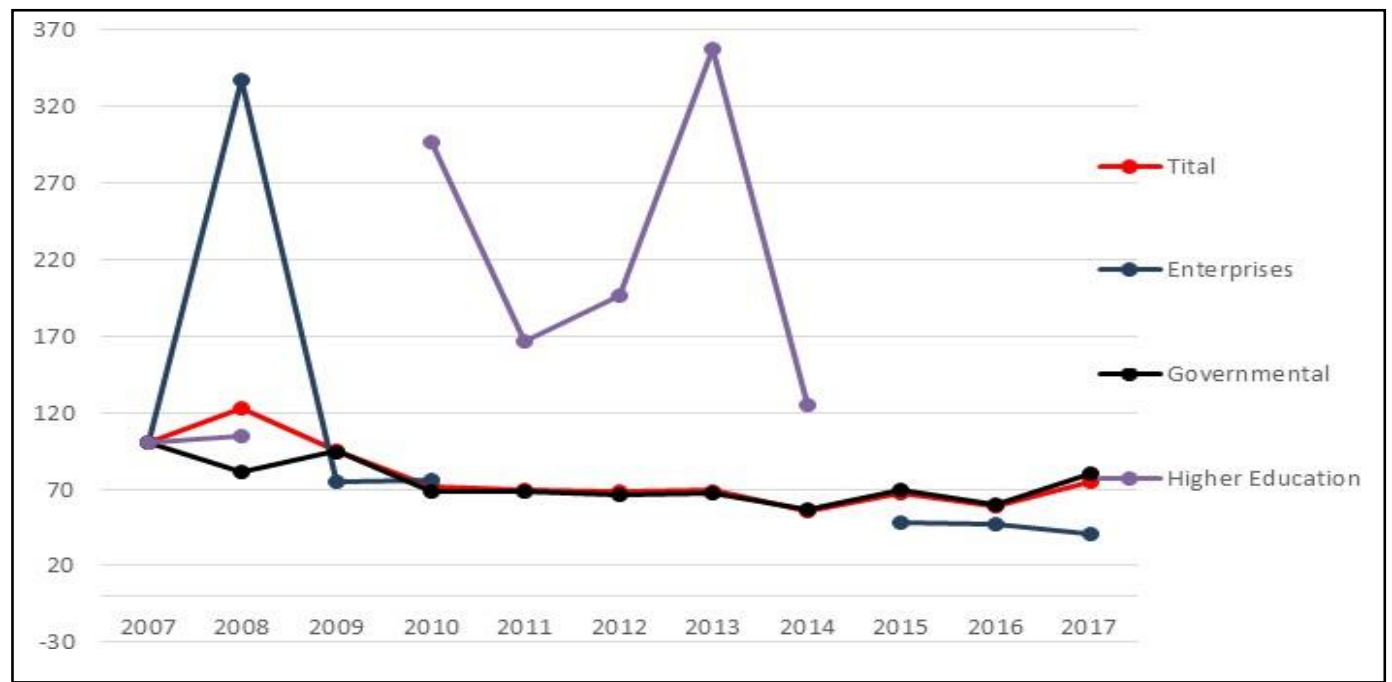

Figure-14. Evolution of Expenditures for R\&D Activity in Agricultural Sciences in Different Sectors of R\&D in Bulgaria $(2007=100)$

Source: NSI National Statistical Institute (2019)

There are no statistical data doe distribution of the number of workforce in the public (state and university) sector of agrarian R\&D activity, but merely in the sector of Enterprises. In the private sector are employed a small portion of the totally involved in agrarian R\&D activity in Bulgaria (Figure 15). The amount of that personnel is little, while their number and share in the overall persons and researchers, engaged in agrarian R\&D activity vary considerably in individual years (from 28 to 66 persons, and between $1,3 \%$ and $2,5 \%)$.

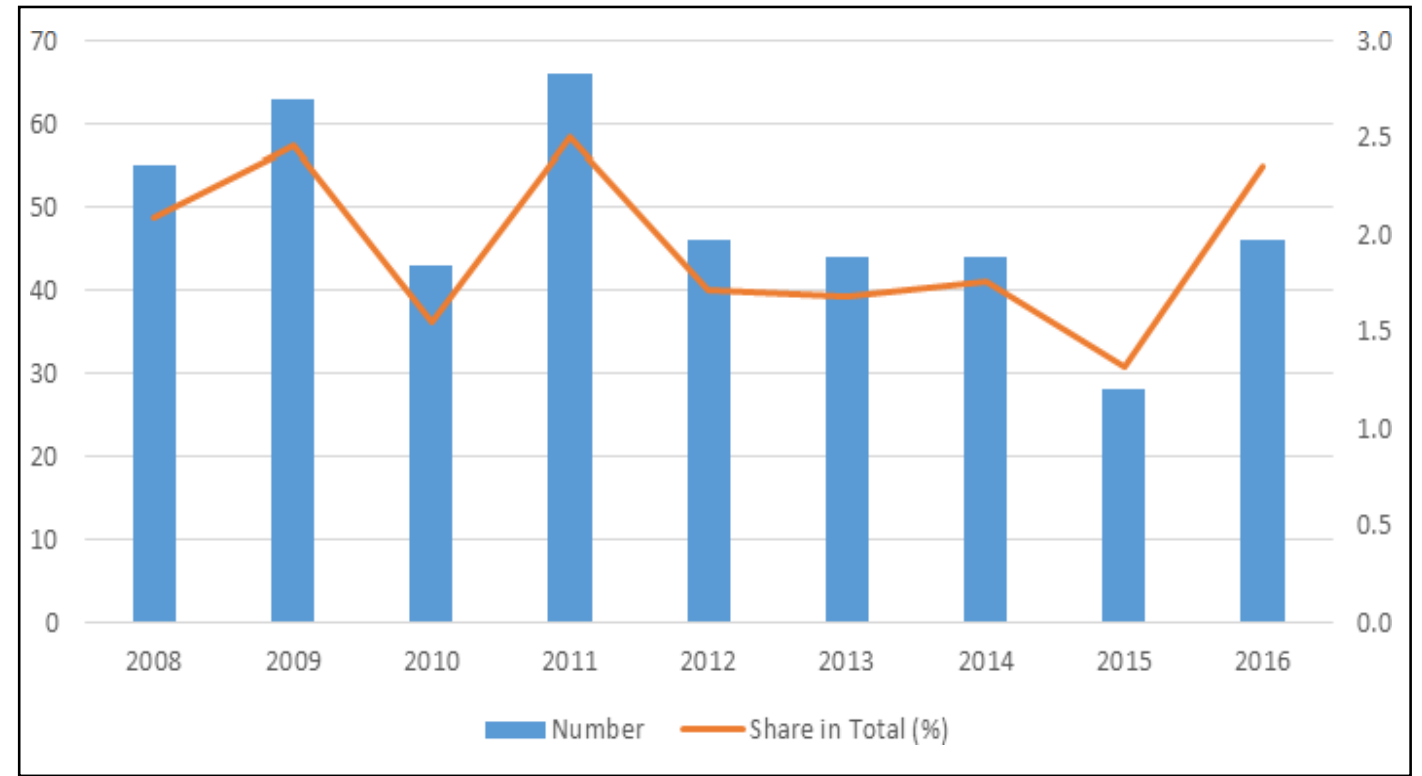

International Journal of Business Management and Finance Research

Vol. 4, No. 2, pp. 82-96

2021

DOI: 10.53935/26415313.v4i2.189

Email: hbachev@yahoo.com

Funding: This study received no specific

financial support.

Article History:

Received: 1 October 2021

Revised: 24 November 2021

Accepted: 8 December 202

Published: 29 December 2021

(0) 2021 by the authors; licensee Academic Publishing Group

Figure-15. Number of Employed in Agricultural R\&D Activity in Sector Enterprises and Share in the Total Employed in R\&D Activity in Agricultural Sciences in Bulgaria Source: NSI National Statistical Institute (2019)

At the same time, the endowment with financial and material resources of employed in agrarian $R \& D$ activity in the private sector (Enterprises) is multiple times higher than in the public sector (Figure 16) Expenditures for one employed in agrarian $R \& D$ activity in the private sector vary significantly in individual year as their level surpasses the average for the country from 5 (2016) to 21 folds (2008). All these expresses the significant lag in development of the governmental and university sectors in financing, payment of labor and modernization of R\&D activity in Bulgarian agriculture in comparison with the business sector. 


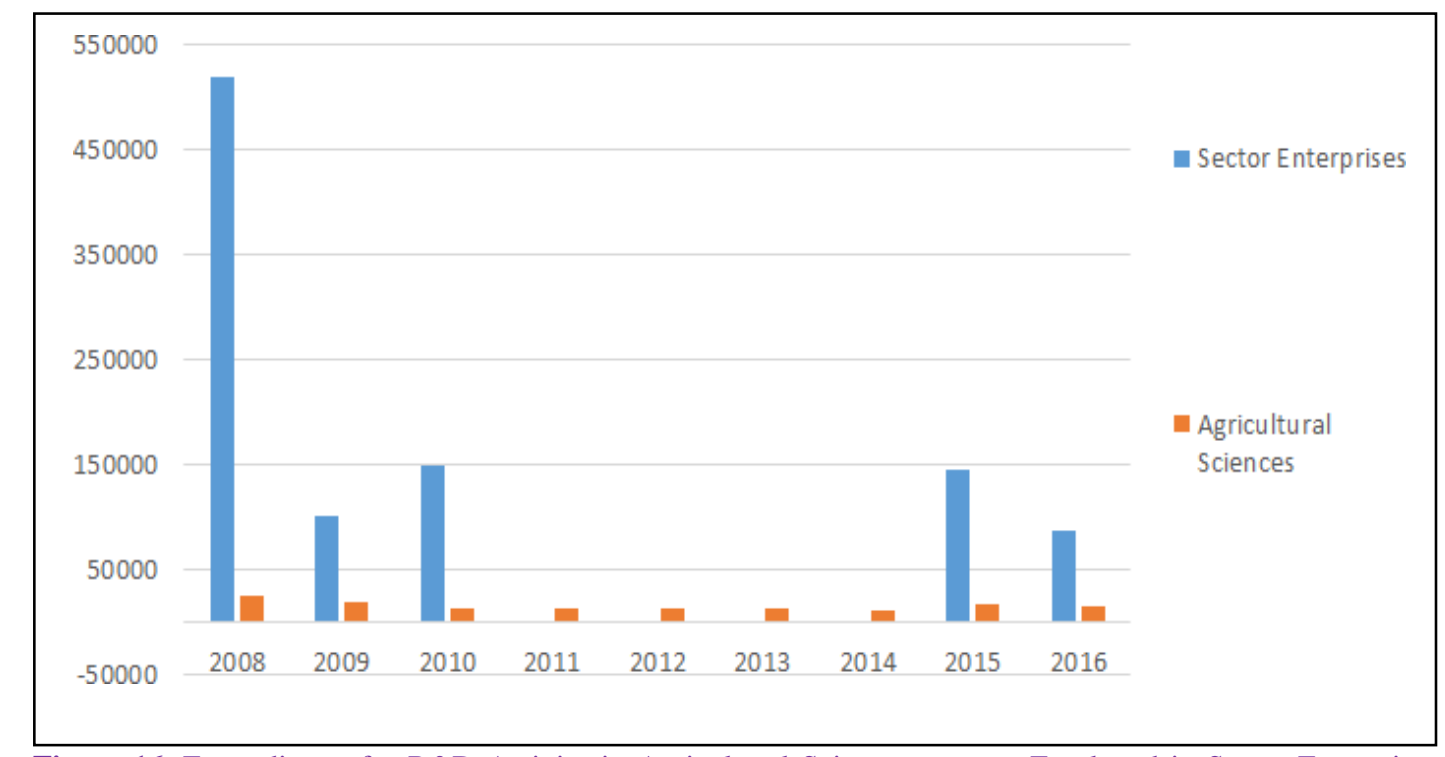

Figure-16. Expenditures for R\&D Activity in Agricultural Sciences per one Employed in Sector Enterprises and Avarage for All Sectors of R\&D in Bulgaria (BGL).

Source: NSI National Statistical Institute (2019).

\section{Funding of Agrarian R and D Activity}

R\&D activity in agrarian sphere in Bulgaria is predominantly funded by the state budget. Approximate idea about the importance of that type of financing is given by ration of the amount of budget appropriations for R\&D activity for Development of Agriculture, Forestry and Fishery- to the expenditures for R\&D activity in Agricultural Sciences-, averaging for the period of 2008-2017 г. at 91,8 (NSI).

The pace of evolution of amount of budget appropriations for agrarian R\&D activity is similar to that of the total expenditures for agrarian R\&D activity, but the decline of the 2008 level is comparatively smaller (with exception for 2010) (Figure 17). That demonstrate that the importance of the budget financing of agrarian R\&D activity relatively increases during the period.

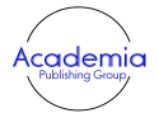

International Journal of Business Management and Finance Research

Vol. 4, No. 2, pp. 82-96

2021

DOI: 10.53935/26415313.v4i2.189

Email: hbachev@yahoo.com

Funding: This study received no specific

financial support.

Recived: I October 2021

Revised: 24 November 2021

Accepted: 8 December 2021

Published: 29 December 2021

() 2021 by the authors; licensee Academic Publishing Group

\section{2}

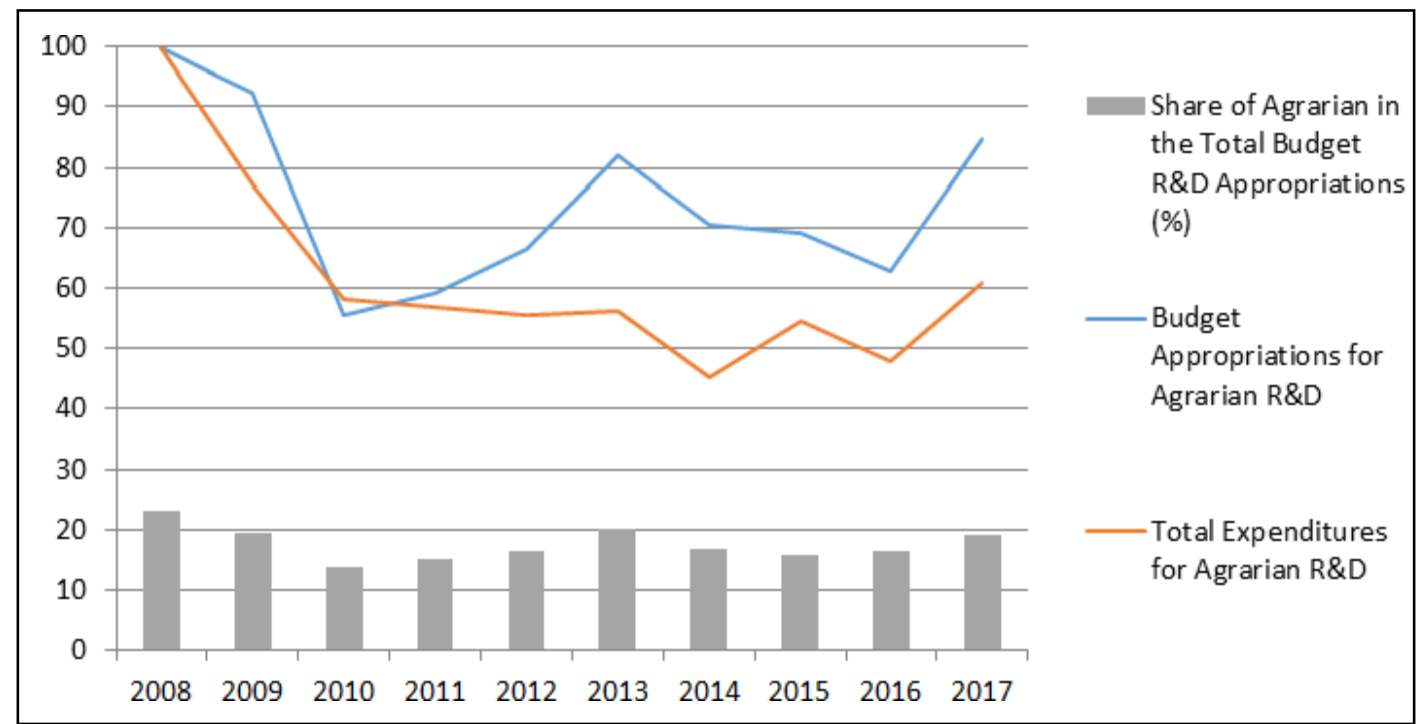

Figure-17. Evolution of Budget Appropriations for R\&D Activity for „Development of Agriculture, Forestry and Fishery -, Share in the Total Budget Appropriations for R\&D Activity, and Evolution of Total Expenditures for R\&D Activity in Agricultural Sciences in Bulgaria (2008=100).

Source: NSI National Statistical Institute (2019).

At the same time however, there is a fall in the share of budget appropriations for R\&D activity for „Development of Agriculture, Forestry and Fishery- sector in the total budget appropriations for 
development of R\&D in the country. What is more, the share of agrarian funding of R\&D activity from the national budget is quite fluctuating as initially dramatically falls (from $23 \%$ in 2008 to 13,9\% in 2013), and after that increases a little bit (up to 19,2\% in 2017). These figures give insight for the diminishing social significance of agrarian R\&D activity and their unsustainable funding by the national budget.

The budget financing of agrarian R\&D activity in Bulgaria is mainly carried out through direct ,institutional- subsidizing of Agricultural Academy and Bulgaria Academy of Sciences ${ }^{3}$, project funding through diverse national, bilateral etc. science programs of the National Science Fund of the Ministry of Education and Science, and projects for innovation in small and middle size enterprises of the National Innovation Fund of the Ministry Of Economy, etc. For instance, $8 \%$ of the budget of the National Science Fund in 2017 is for „Agricultural Sciences- - for 11 projects $45 \%$ of which for the institutes of the Agricultural Academy, 36\% for the institutes of the Bulgaria Academy of Sciences, and the rest for 2 universities (MES). Implemented programs of the funding agencies aim at achievement of the strategic priorities of the country (competitiveness, sustainable development, etc.), and they are in line with EU priorities.

Since 2009 now in EU as a whole there are slight fluctuations in both directions in the level of budget appropriations for agrarian R\&D activity (Figure 18). However, in individual member states there is unlike changes in the financing from the national budget of R\&D activity in agriculture. In Germany and France budget appropriations for agrarian R\&D activity experience constant growth. In Check Republic budget appropriations falls a little bit, and recover initial level afterwards. In Austria and Romania there is initial augmentation of the budget support and subsequent drop below initial level.

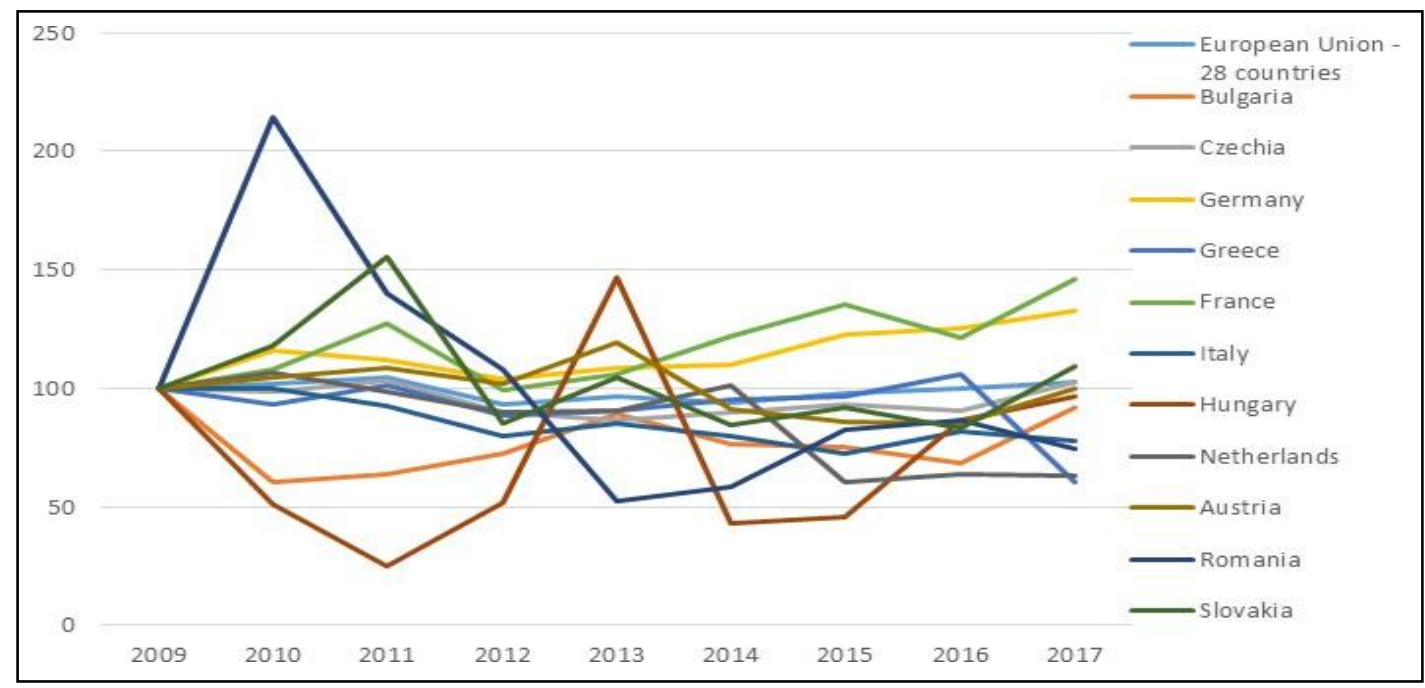

Figure-18. Evolution of Government Budget Appropriations or Outlays on R\&D in Agriculture in EU Member States $(2009=100)$

Source: (Eurostat, 2019).

In most EU member states there is a tendency for permanent reduction of the importance of the state budget in the sustentation of R\&D activity of agriculture. What is more, for certain countries like Greece, Netherlands and Italy the decline of the budget funding of agrarian R\&D activity in recent years is significantly greater than in Bulgaria.

Private business investments in R\&D activity are „market oriented- and aim at satisfying some practical

International Journal of Business Management and Finance Research Vol. 4, No. 2, pp. 82-96

2021

DOI: $10.53935 / 26415313 . v 4 i 2.189$

Email:hbachev@yahoo.com

Funding: This study received no specific

financial support.

Article History:

Received: 1 October 2021

Revised: 24 November 2021

Accepted: 8 December 2021

Published: 29 December 2021

(๑) 2021 by the authors; licensee Academic

Publishing Group

93 needs of innovation and realization of economic and other benefits (profit, improving market positions and relations with counterparts, modernization and atomatization of processes, introduction of know-how, new products and technologies, etc.). They are also a means for direct connection of interested parties and effective sharing of knowledge and innovation for satisfaction of specific needs in agrarian sphere.

The level of business expenditures (of Enterprises) for R\&D activity in „Agriculture, Forestry and Fishery-sector in Bulgaria varies substantially in different years (Figure 19). 


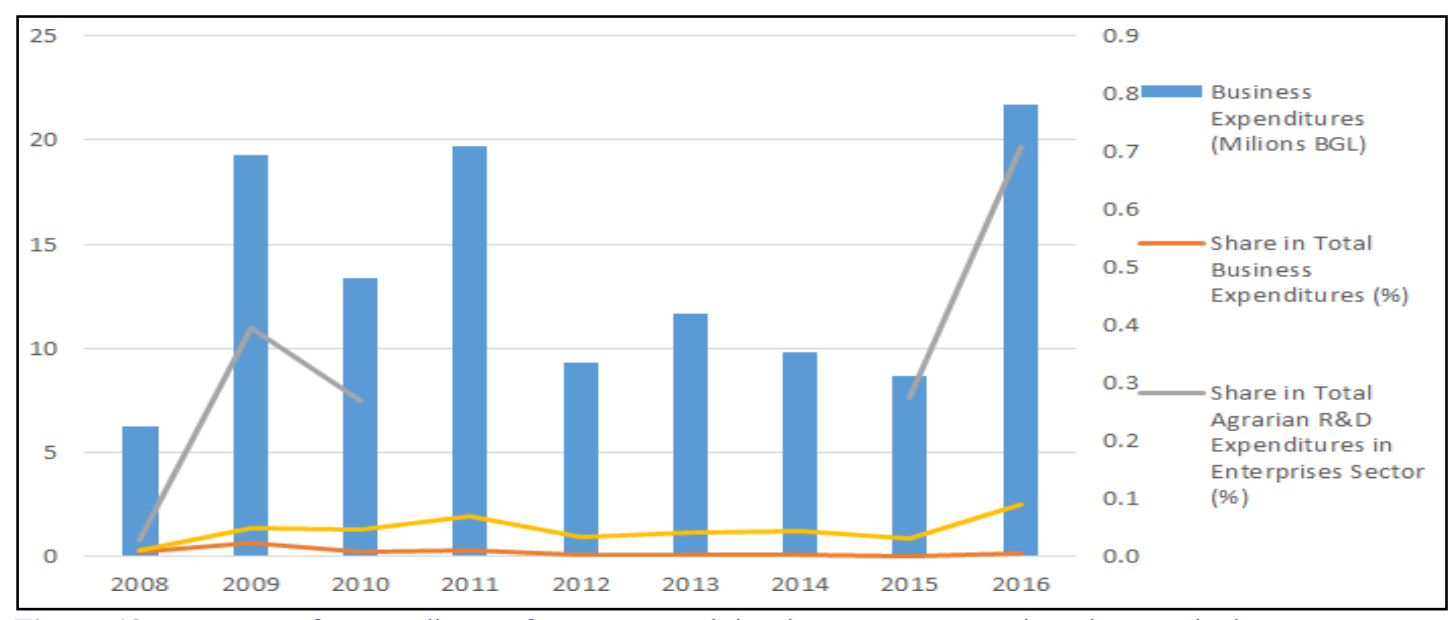

Figure-19. Amount of Expenditures for R\&D Activity in Sector Enterprises in „Agriculture, Forestry and Fishery- and Share in the Total Expenditures for R\&D Activity in „Agricultural Sciences- in Bulgaria.

Source: NSI National Statistical Institute (2019)

The share of the private sector for financing agrarian R\&D activity is insignificant, as they account for a tiny portion $(0,05-0,31 \%)$ of the total business investments in R\&D activity of the country. The later demonstrates that incentives for business investments in R\&D activity in agriculture are still small generally as well as in comparison with other sectors of the economy. Above is also supported by the fact that the expenditures of the enterprises for agrarian R\&D still comprise relatively little share of the total expenditures for agrarian R\&D activity of the country - from $0,35 \%$ to $2,5 \%$. That indicates besides lack of sufficient incentives (profit, other benefits) also low (staff, technical, financial, etc.) capability for private R\&D activity at the contemporary stage of development of Bulgarian agriculture. However, for carried in the sector of Enterprises agrarian R\&D activity, in individual years private (business) investments in agrarian R\&D activity accounts a good proportion of the overall expenditures for R\&D activity of Enterprises (from 7,5\% to almost 20\%). The later confirms, that when there are sufficient incentives and benefits the private sector actively involves in funding and execution of R\&D activity in the sector. Bulgaria, along with Lithuania and Slovenia are among the countries of EU with the smallest share of the business expenditures for R\&D activity in „Agriculture, Forestry and Fishery- in the total expenditures for R\&D activity in the sector „Agriculture(Figure 20). In certain countries, like Romania and Hungary, private funding of R\&D activity represents a considerable portion in the R\&D activity of agriculture.

International Journal of Business Management and Finance Research Vol. 4, No. 2, pp. 82-96

2021

DOI: 10.53935/26415313.v4i2.189

Email: hbachev@yahoo.com

Funding: This study received no specific

financial support.

Received: 1 October 2021

Revised: 24 November 2021

Accepted: 8 December 2021

Published: 29 December 2021

() 2021 by the authors; licensee Academic Publishing Group

\section{| 94}

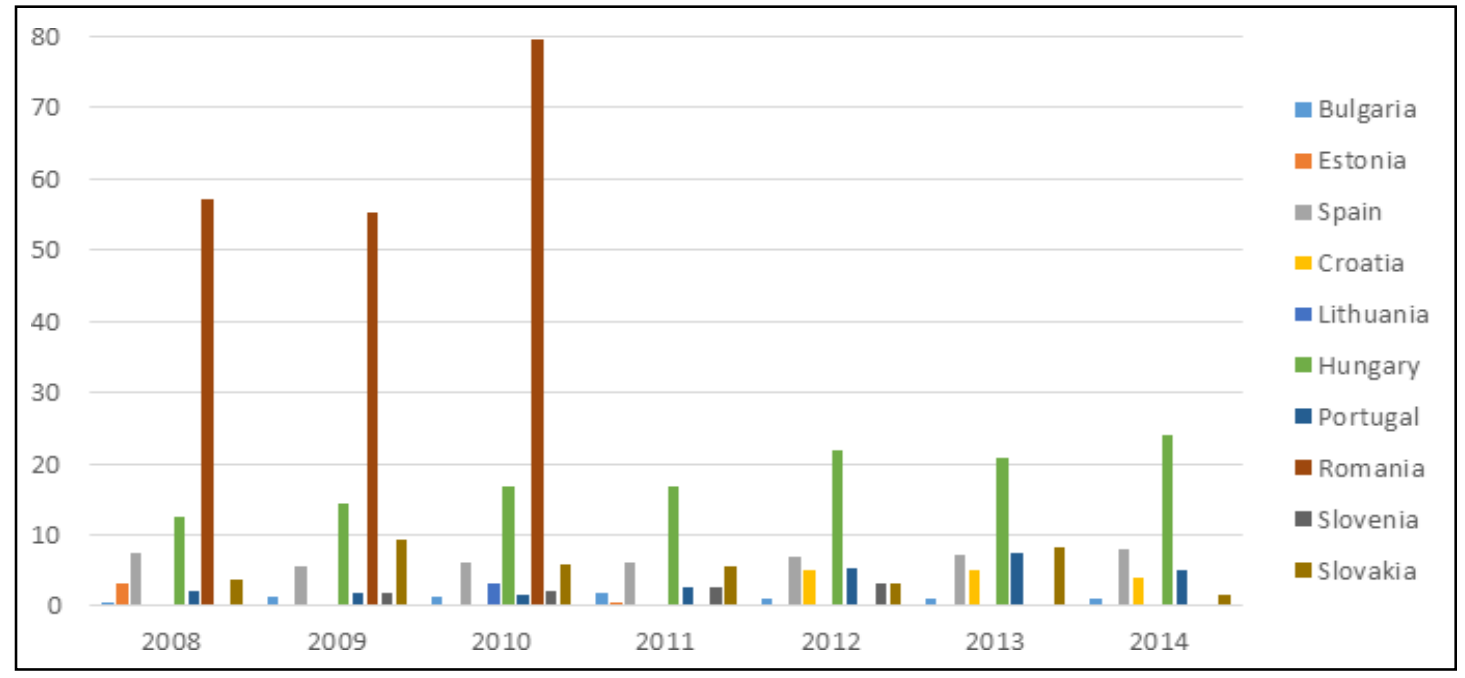

Figure-20. Share of Business Expenditures on R\&D in „Agriculture, forestry and fishing- in Total Intramural R\&D Expenditures in Sector,,Agriculture- in EU Member States (\%). Source: Eurostat. 
In the EU member state there are several trends in the size of business expenditures for R\&D activity in agriculture during the period 2008-2016, for which data are available (Figure 21).

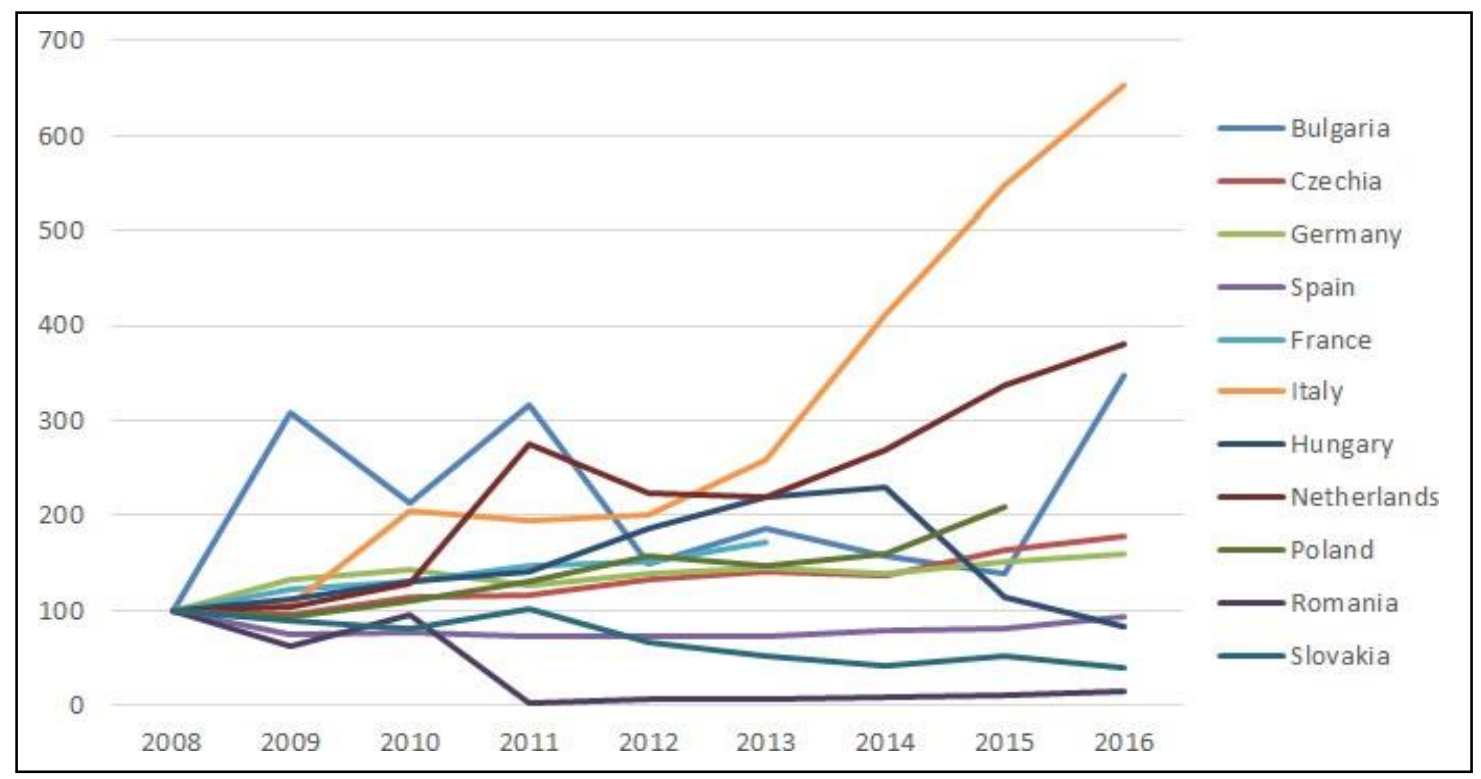

Figure-21. Evolution of Business Expenditures on R\&D in „Agriculture, forestry and fishing- in EU Member States $(2008=100)$.

Source: Eurostat (2019).

In the first groups are countries, in which the business expenditures for R\&D activity in agriculture show constant (France, Check Republic and Poland) and significant (Italy and Netherlands) growth.

In other group countries (Romania and Slovakia), the amount of business investments in agrarian R\&D activity demonstrate sizable drop.In a third group of countries the level of private expenditures for R\&D are relatively stable during the analyzed period after initial decline (Spain) or upsurge (Germany).

And finally, there are countries like Bulgaria and Hungary where business expenditures in agrarian R\&D of enterprises fluctuate significantly up and down in different years.

\section{Conclusions}

During the years since the accession of Bulgaria to EU expenditures for R\&D in agricultural sciences considerably decrease both absolutely as well as relatively as a share in the total investments in R\&D of the country. That indicates diminishing importance and deteriorating financial and material endowment of agrarian sector of knowledge and innovation. In the past several years the personnel endowment for R\&D activity in agrarian sphere also deteriorate due to a great reduction of persons employed in R\&D activity in sector Agricultural Sciences as well as their relative share in the overall workforce of R\&D activity of the country.The most important sector of agricultural R\&D activity in the country is the governmental one, in which are invested more than $80 \%$ of overall expenditures for R\&D activity in agriculture. Distribution of the expenditures and organization of $\mathrm{R} \& \mathrm{D}$ activity in the major sectors of agrarian R\&D activity in Bulgaria differ greatly from other member state of EU, in most of which the government sector dominates, but with a considerably lower share et the expense of sector Higher Education and strongly developed private (business) sector of agrarian R\&D activity. All this demonstrates unbalanced development of main sectors of agrarian R\&D activity in Bulgaria in a direction unlike common trends in EU and other developed countries.

R\&D activity in agrarian sphere in Bulgaria is predominantly financed by the state budget, as the role of budget funding of agrarian $\mathrm{R} \& \mathrm{D}$ activity relatively increases during the period. That trend is dissimilar to most EU member states where there is a constant diminution of the importance of the national budget appropriations in the overall R\&D activity of agriculture.

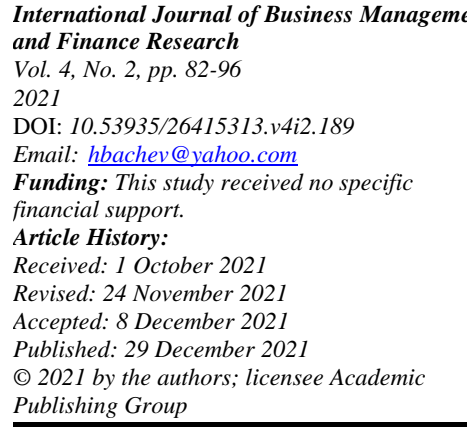




\section{References}

Anandajayasekeram, P., \& Gebremedhin, B. (2009). Integrating innovation systems perspective and value chain analysis in agricultural research for development: Implications and challenges. Improving productivity and market success (IPMS) of Ethiopian farmers project working paper 16. Nairobi: International Livestock Research Institute.

Antle, J. M., Jones, J. W., \& Rosenzweig, C. E. (2017). Next generation agricultural system data, models and knowledge products: Introduction. Agricultural Systems, 155, 186-190.

Bachev, H., \& Labonne, M. (2000). About the organization of agrarian innovations, rural economics and sociology station: National Higher Agronomic School: ENSA, INRA.

Bachev, H., \& Mihailova, M. (2019). Analysis of the state of the system of sharing of knowledge and innovations in bulgarian agriculture, econpapers. Retrieved from https://econpapers.repec.org/paper/pramprapa/94230.htm.

Chartier, O., Doghmi, M., Fourcin, C., Broek, M., \& Midmore, P. (2015). Investment in agricultural research in Europe: Synthesis report. IMPRESA Project, EC 7th Framework Programme.

European Commission. (2018). Proposal for a regulation of the european parliament and of the council. In Establishing Rules on support for Strategic plans to be Drawn up by Member States under the Common Agricultural Policy (CAP Strategic Plans) and Financed by the European Agricultural Guarantee Fund (EAGF) and by the European Agricultural Fund for Rural Development (EAFRD) and Repealing Regulation (EU) No 1305/2013 of the European Parliament and of the Council and Regulation (EU) No 1307/2013 of the European Parliament and of the Council. Brussels: European Commission.

Eurostat. (2019). Variouse data. Retrieved from https://ec.europa.eu/eurostat/data/browse-statistics-by-theme.

FAO. (2019). Communication in research and development. FAO. Retrieved from http://www.fao.org/3/v9406e/v9406e02.htm.

Ivanov, B., Popov, R., Bashev, H., Koteva, N., Malamova, N., Chopeva, M., \& Mitova, D. (2020). Report analysis of the state of agriculture and the food industry swot analysis: IAI.

Mykhailova, L., Stoyanets, N., Mykhailov, A., Kharchenko, T., \& Bachev, H. (2018). Sustainable development of the Ukrainian agrarian sector: Perspectives and challenges. Problems and Perspectives in Management, 16(3), 28-39.

NSI National Statistical Institute. (2019). National Statistical Institute, various data. Retrieved from https://infostat.nsi.bg/infostat/pages/module.jsf?x_2=12\&lang=bg.

Ozçatalbaş, O. (2017). Human development and research-development-extension relationships. Towards Human, Institutional and Economic Sectors Growth, 13.

Touzard, J. L., Temple, G. F., \& Triomphe, B. (2015). Innovation systems and knowledge communities in the agriculture and agrifood sector: A literature review. Journal of Innovation Economics and Management, 2(17), 117-142.

USDA. (2019). Agricultural research funding in the public and private sectors. USDA. Retrieved from https://www.ers.usda.gov/dataproducts/agricultural-research-funding-in-the-public-and-private-sectors/.

Virmani, S. (2013). Public-private partnership and policy reforms for effective agricultural research, development, and training. In $G$. Bhullar and N. Bhullar, Agricultural Sustainability: Elsevier.

Weißhuhn, P., Helming, K., \& Ferretti, J. (2018). Research impact assessment in agriculture-a review of approaches and impact areas. Research Evaluation, 27(1), 36-42.Available at: https://doi.org/10.1093/reseval/rvx034.

World Bank. (2006). Enhancing agricultural innovation: How to go beyond the strengthening of research systems. Washington D. C: The International Bank for Reconstruction and Development / The World Bank.

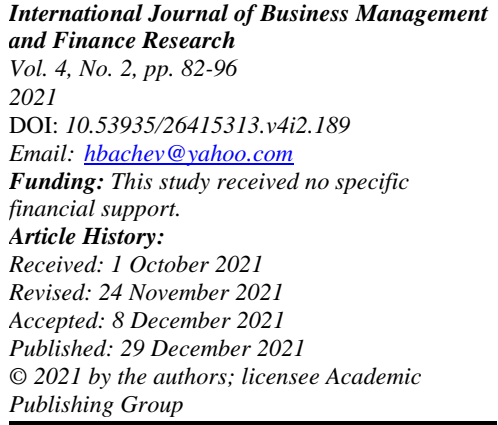
Publishing Group 